\title{
TOWARDS THE MODELING OF GLACIER MICROTOPOGRAPHY USING HIGH- RESOLUTION DATA FROM UNMANNED AERIAL SURVEY
}

\author{
I. V. Florinsky ${ }^{1, *}$, T. N. Skrypitsyna ${ }^{2}$, D. P. Bliakharskii ${ }^{3}$, O. T. Ishalina ${ }^{3}$, A. S. Kiseleva ${ }^{2}$ \\ ${ }^{1}$ Institute of Mathematical Problems of Biology, Keldysh Institute of Applied Mathematics, Russian Academy of Sciences, \\ 1 Vitkevich Street, Pushchino, Moscow Region, 142290, Russia - iflor@mail.ru \\ ${ }^{2}$ Department of Photogrammetry, Moscow State University of Geodesy and Cartography (MIIGAiK), \\ 4 Gorokhovsky Lane, Moscow, 105064, Russia - (tatyana.skrypitsyna, ennnot)@yandex.ru \\ ${ }^{3}$ Department of Cartography and Geoinformatics, Institute of Earth Sciences, St. Petersburg University, \\ 7-9 University Embankment, St. Petersburg, 199034, Russia - (rash55, olya-ishalina)@yandex.ru
}

KEY WORDS: Digital Terrain Modeling, Geomorphometry, Unmanned Aerial Survey, Microtopography, Glacier

\begin{abstract}
:
Glaciated areas are important targets for interdisciplinary research. In the last quarter of the 20th century, there has been a significant shift in glacier observation approaches from direct fieldwork to remote sensing. Over the past 15 years, unmanned aerial systems have been increasingly used for this purpose. In this article, we briefly describe a newly launched Russian-Chinese project aimed at developing a theory and methodology for digital modeling and analysis of the glacier microtopography using very high resolution data from unmanned aerial surveys. We argue the relevance of the study and review key publications on the application of digital terrain modeling and geomorphometry in glaciology. Next, we discuss the aim of the project and tasks performed by the Russian side, as well as materials and methods used in the study. As initial data, we use multi-temporal, digital aerial images of very high resolution $(5 \mathrm{~cm})$ collected by the unmanned aerial survey of the ice sheet and glaciers near the Larsemann Hills, East Antarctic. Finally, we present some examples for geomorphometric analysis of glacier microtopography including snow/ice features of eolian origin.
\end{abstract}

\section{INTRODUCTION}

Glaciated areas are important targets for interdisciplinary research. This is due to a number of political, economic, and scientific factors.

First, one of the core political tasks of the Russian Government is to ensure the development of the Arctic territories, which are a zone of Russia's strategic interests. An equally important geopolitical goal is to ensure the Russian presence in the Antarctic region. In addition, access to fresh water sources, including glaciers, gradually becomes a serious tool of various political actors, especially in arid zones of Central Asia.

Second, glaciated areas have a significant impact on climate change at the global and regional scales. On the other hand, glacier dynamics is an indirect indicator of regional climate changes.

Third, glaciers are in continuous motion leading to constant changes in the geometry of glacial topography at different spatial scales (from macro- to microtopography). Such changes can be both slow and catastrophic. In particular, dangerous crevasses and subsidences are formed in glacier surfaces. Some natural processes in glaciers and ice sheets (e.g., outbursts of water from glacier lakes) can lead to catastrophic consequences in the adjacent valleys. In this regard, safety studies, prompt monitoring, and mathematical modeling of glaciers are important.

In the last quarter of the 20th century, there has been a significant shift in glacier observation approaches from direct fieldwork to remote sensing. Over the past 15 years, unmanned aerial systems (UASs) have been increasingly used for this purpose. In particular, one of the most promising approaches for studying glaciers is their mathematical modeling and simulation using digital elevation models (DEMs) of high and ultra-high resolution produced from UAS-based data.

\section{DIGITAL TERRAIN MODELING IN GLACIOLOGY: A SHORT REVIEW}

\subsection{Achievements}

The application of digital terrain modeling in glaciology began in the 1990s. Suetova and Chistov (1993) created small-scale DEMs for portions of Antarctica using cartographic materials. Etzelmüller and Sollid (1997) introduced a concept of glacial geomorphometry and created a series of DEMs for Svalbard using multi-temporal aerial images. Later on, researchers used medium- and small-scale DEMs of individual glaciers, their portions, and the whole of Antarctica and Greenland. Such DEMs - with resolutions of meters as well as tens and hundreds of meters - are usually created from topographic maps, aerial and satellite imagery, as well as ground topographic and lidar data. These DEMs are used to assess and study the dynamics of glaciers and snow fields, their volumes, and so on (Pogorelov, 1999; Etzelmüller, 2000; Knizhnikov et al., 2000, 2002; Rippin et al., 2003; DiMarzio et al., 2005; Racoviteanu et al., 2007; Fox, Cziferszky, 2008; Kääb, 2008; Zolotarev, 2009; Bamber et al., 2009; Bhambri, Bolch, 2009; Boyko, 2010; Fretwell et al., 2013; Helm et al., 2014; Semakova, Semakov, 2017). The low resolution of such DEMs imposes serious limitations on the ability to study and model glacial processes.

* Corresponding author 
Unmanned aerial survey of glaciers was initiated by Hodson et al. (2007). This approach and UAS-derived DEMs with centimeter and decimeter resolution are used, for example, for detailed analysis of glacier dynamics, glacier velocity, and studies of glacier drainage network (Whitehead et al., 2013; Immerzeel et al., 2014; Rippin et al., 2015; Ryan et al., 2015; Bhardwaj et al., 2016; Kraaijenbrink et al., 2016; Jouvet et al., 2017; Wigmore, Mark, 2017; Pogorelov et al., 2017; Bash et al., 2018; Petrakov et al., 2018). High resolution of such DEMs, in principle, enables research and modeling of glacial processes at the microtopographic scale.

\subsection{Remaining Challenges}

Despite the achievements, it is a non-trivial task to model glacier microtopography using high and very high resolution data from UAS surveys. This is mostly associated with physical properties of an ice/snow surface.

First, a UAS survey should be performed in sunny weather, or at variable and high cloudiness (Bliakharskii et al., 2019a). In this case, one can obtain contrast images with clearly visible, wind-created microtopographic ice/snow features. These microfeatures are used by correlation algorithms in searching tie points to construct a dense point cloud. It is highly undesirable to conduct a UAS survey under low cloudiness (and so diffuse lighting). In this case, one obtains low-contrast, whitish aerial images, with unrecognizable ice/snow microfeatures.

Second, glacier DEMs of a very high resolution can include myriads of high-frequency patterns, which represent not only microtopographic ice/snow features but also noise/artifacts. The latter are caused by both specificities of the formation of highresolution images of the glistening ice/snow surface and photogrammetric processing of such aerial photographs. The geomorphometric maps derived from such DEMs are almost unreadable and so useless (Florinsky, Bliakharskii, 2019a). The problem is that it is impossible to suppress or remove correctly such noise and artifacts. This is because, in the case of a very high resolution glacier DEM, noise and signal levels can be comparable, so filtering may equally remove patterns of both the noise and signal.

Another unsolved problem of unmanned aerial survey of glaciers is the difficulty or impossibility to create and utilize a network of ground control points. This is due to safety reasons and restrictions (e.g., crevasse danger) as well as the continuous movement of the glacier surface. Application of the direct georeferencing approach (Chiang et al., 2012; Turner et al., 2014) can help solve this problem.

Over the past 20 years, progress has been made in the development of the theory and methods of digital terrain modeling and geomorphometry (Wilson, Gallant, 2000; Shary et al., 2002; Hengl, Reuter, 2009; Florinsky, 2016, 2017; Wilson, 2018). However, these advances have not yet been properly used in both processing of UAS-based data and glaciological studies.

\section{AIM AND TASKS OF THE PROJECT}

In spring 2020, we started a two-year, Russian-Chinese project to fill these gaps. The project is a continuation of our recent works (Florinsky et al., 2018; Florinsky, Bliakharskii, 2019a, 2019b; Bliakharskii, 2019; Bliakharskii et al., 2019a, 2019b, 2020).
The aim of the project is to develop a theory and methodology of mathematical modeling and analysis of glacier microtopography using UAS-derived data of high and ultrahigh resolution. Among others, the following tasks are undertaken by the Russian side to achieve this objective:

1. To develop the theory of mathematical modeling of the glacier microtopography using UAS-derived data of high and ultra-high resolution.

2. To develop a computational geomorphometric method for crevasse detection based on UAS-derived data.

3. To develop a computational geomorphometric method for determining the horizontal and vertical velocity of the glacier flow based on multi-temporal, UASderived data using the direct georeferencing approach.

4. To carry out three-dimensional (3D) modeling of the glacier microtopography for the Larsemann Hills area, East Antarctica using UAS-derived aerial imagery of high and ultra-high resolution.

5. To test the developed theory and methods for analyzing the evolution of the glacier microtopography exemplified by the Larsemann Hills area.

\section{STUDY AREA}

The study was conducted at the ice sheet and glaciers near the Larsemann Hills, East Antarctica (Fig. 1). The Larsemann Hills are ice-free, low rounded hills with an area of about $40 \mathrm{~km}^{2}$ located on the southeastern coast of the Prydz Bay, Princess Elizabeth Land (Stüwe et al. 1989). There are three year-round operated polar stations in this area: Progress (Russia), Zhongshan (China), and Bharati (India).

\section{MATERIALS AND METHODS}

\subsection{UAS Survey}

As initial data, we use multi-temporal, digital aerial images of a very high resolution $(5 \mathrm{~cm})$ collected by the unmanned aerial survey of the ice sheet and glaciers near the Larsemann Hills. The surveys were performed, inter alia, during the 62nd Russian Antarctic Expedition (December 2016 - February 2017) (Bliakharskii et al., 2019a).

In particular, we use data from the unmanned aerial survey of a portion of the sledge route from the Progress to Vostok Stations, from 69 $27^{\prime} 24^{\prime \prime} \mathrm{S}, 76^{\circ} 19^{\prime} 04^{\prime \prime} \mathrm{E}$ to $69^{\circ} 40^{\prime} 40^{\prime \prime} \mathrm{S}$, 76 32'46" E (Bliakharskii et al., 2019a). The sledge route area had a length of $\sim 30 \mathrm{~km}$ and a width of $\sim 3 \mathrm{~km}$. This area is a snow-covered ice sheet surface gradually rising to the south, from $284 \mathrm{~m}$ to $734 \mathrm{~m}$ above sea level.

The UAS survey of the sledge route area was conducted by Geoscan 201 Geodesy (Fig. 2), a professional-grade flying-wing UAS (Geoscan, 2016). The Geoscan 201 Geodesy was equipped with the following instruments:

1. A modem for communication with a laptop ground control station (as the ground GNSS base station, a receiver Topcon HiPer V was used).

2. A Topcon b110 GNSS receiver (GPS + GLONASS, $\mathrm{L} 1+\mathrm{L} 2)$. 


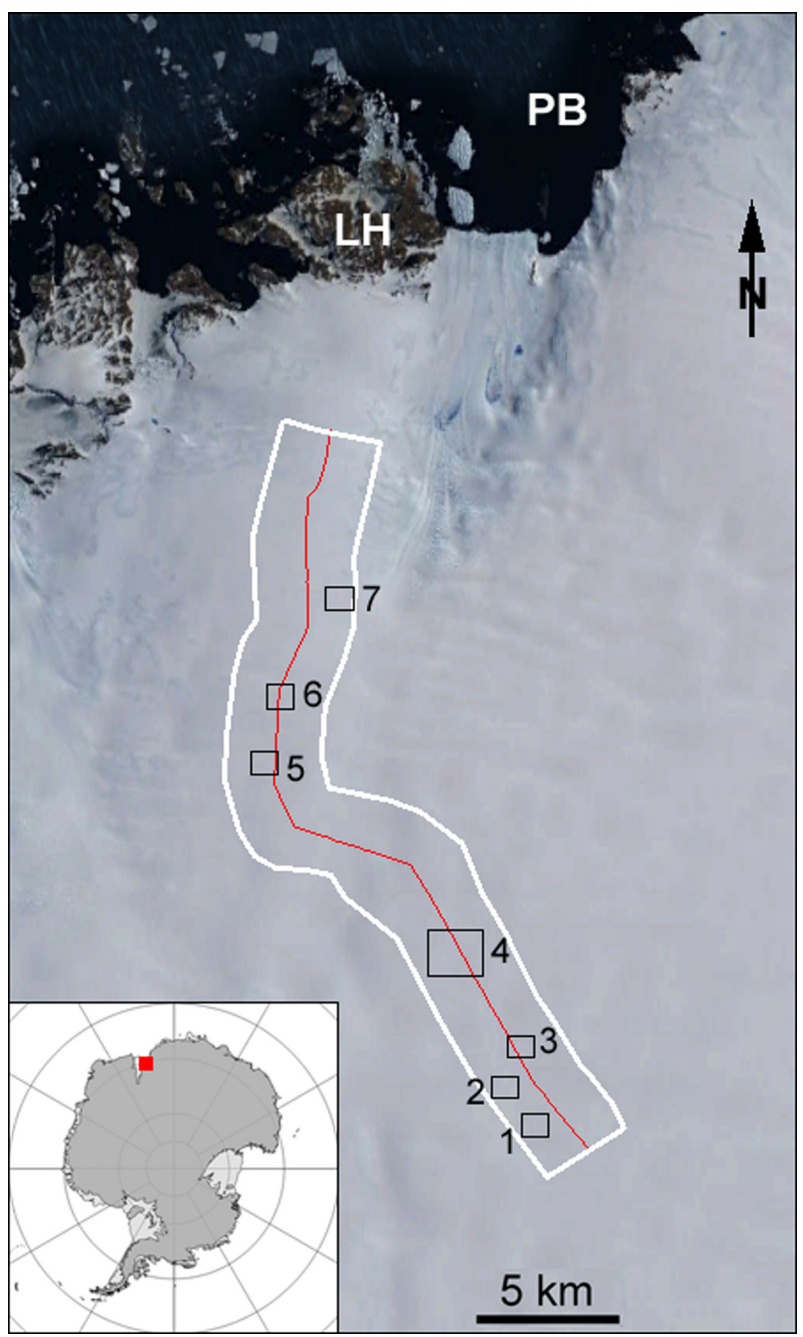

Figure 1. Geographical location of the surveyed area on the background of the U.S. Geological Survey image mosaic (from the Google Earth). The white frame - the area of the initial section of the sledge route (the red line) from the Progress to

Vostok Stations. Black frames 1-7 - sites for studying microtopographic snow/ice features of eolian origin (see Figs. 4-8). LH - Larsemann Hills; PB - Prydz Bay

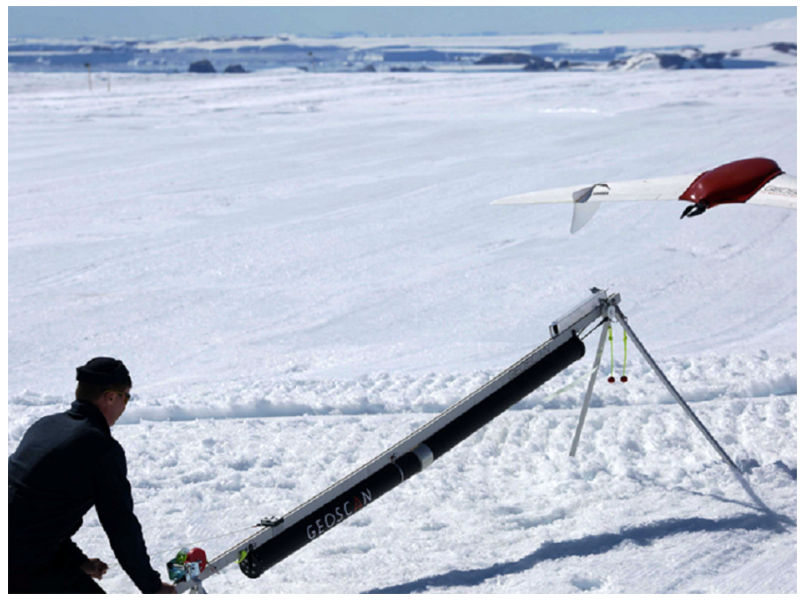

Figure 2. The Geoscan 201 Geodesy launching by a catapult at the study area
3. A field-calibrated, visible-band camera Sony DSCRX1 with a Carl Zeiss Vario Sonnar T lens (a $35 \mathrm{~mm}$ focal length, a central leaf shutter) and a sensor $(35.8 \mathrm{~mm} \times 23.9 \mathrm{~mm}$, a 6,000 pixels $\times 4,000$ pixels matrix with pixel sizes of $6 \mu \mathrm{m} \times 6 \mu \mathrm{m})$. The following settings for the camera were applied: (1) the lens was locked at infinity; (2) the shutter priority was at $1 / 1,000 \mathrm{~s}$ and $1 / 800 \mathrm{~s}$ for sunny and cloudy weather, correspondingly; (3) an aperture and ISO sensitivity were automatically selected per a flight strip.

The sledge route area was twice surveyed, in mid-January 2017 and early February 2017. During the first survey, the weather was good: there was sunny; the air temperature ranged from $-5^{\circ} \mathrm{C}$ to $-10^{\circ} \mathrm{C}$; the wind speed was $10-15 \mathrm{~m} / \mathrm{s}$ gusting up to 18 $20 \mathrm{~m} / \mathrm{s}$ at the flight altitude of $300-430 \mathrm{~m}$. The wind was south katabatic in morning and north afternoon. The first survey consisted of 9 flights (195 flight strips including 9,381 images) for area of $\sim 102 \mathrm{~km}^{2}$. However, the weather deteriorated during the second survey: there was overcast with a cloud base of about $1000 \mathrm{~m}$; the air temperature ranged from $-7^{\circ} \mathrm{C}$ to $-12^{\circ} \mathrm{C}$; the wind speed was $15-20 \mathrm{~m} / \mathrm{s}$ gusting up to $25-28 \mathrm{~m} / \mathrm{s}$ at the flight altitude of $300-430 \mathrm{~m}$. As a result, the second survey consisted of 5 flights (126 flight strips including 6,196 images) for the area of $\sim 73 \mathrm{~km}^{2}$.

The flights were performed using an autopilot at a constant altitude above ground level. Each flight took about 2 hrs. For all flights, forward and side overlaps were about $70 \%$ and $50 \%$, correspondingly. Aerial images have an average resolution of 6 cm (Bliakharskii et al., 2019a).

\subsection{Data Processing}

To implement the direct georeferencing approach, we use Pinnacle 1.0, Trimble Business Center 2.0, and Magnet Office Tools 2.8 to process on-board GNSS receiver measurements and ground geodesic measurements. For processing UASderived imagery, we use software Agisoft PhotoScan Professional 1.3.2, Agisoft MetaShape Professional 1.5, and Photomod 6.0.

For the sledge route area, in particular, data treatment included the following key stages (Bliakharskii et al., 2019a):

1. Determination of the high-precision coordinates of image projection centers. This information was used for the post-processed kinematic direct georeferencing (Turner et al., 2014).

2. Alignment of images by the least-squares bundle adjustment using data from the camera field calibration. The aerial triangulation accuracy was as follows: planimetric $\mathrm{X}=1.90 \mathrm{~m}, \mathrm{Y}=0.50 \mathrm{~m}$; vertical $\mathrm{H}=0.80 \mathrm{~m}$.

3. Construction of a dense point cloud by the Agisoft semi-global matching algorithm.

4. Generation of a DEM applying triangulation and smooth interpolation of the dense point cloud.

5. Production of orthomosaics.

For the sledge route area, we produced two 1-m gridded DEMs related to mid-January 2017 and early February 2017 dates of the UAS surveys (Fig. 3). As horizontal and vertical datums, we applied WGS 1984 and EGM 2008, correspondingly. 


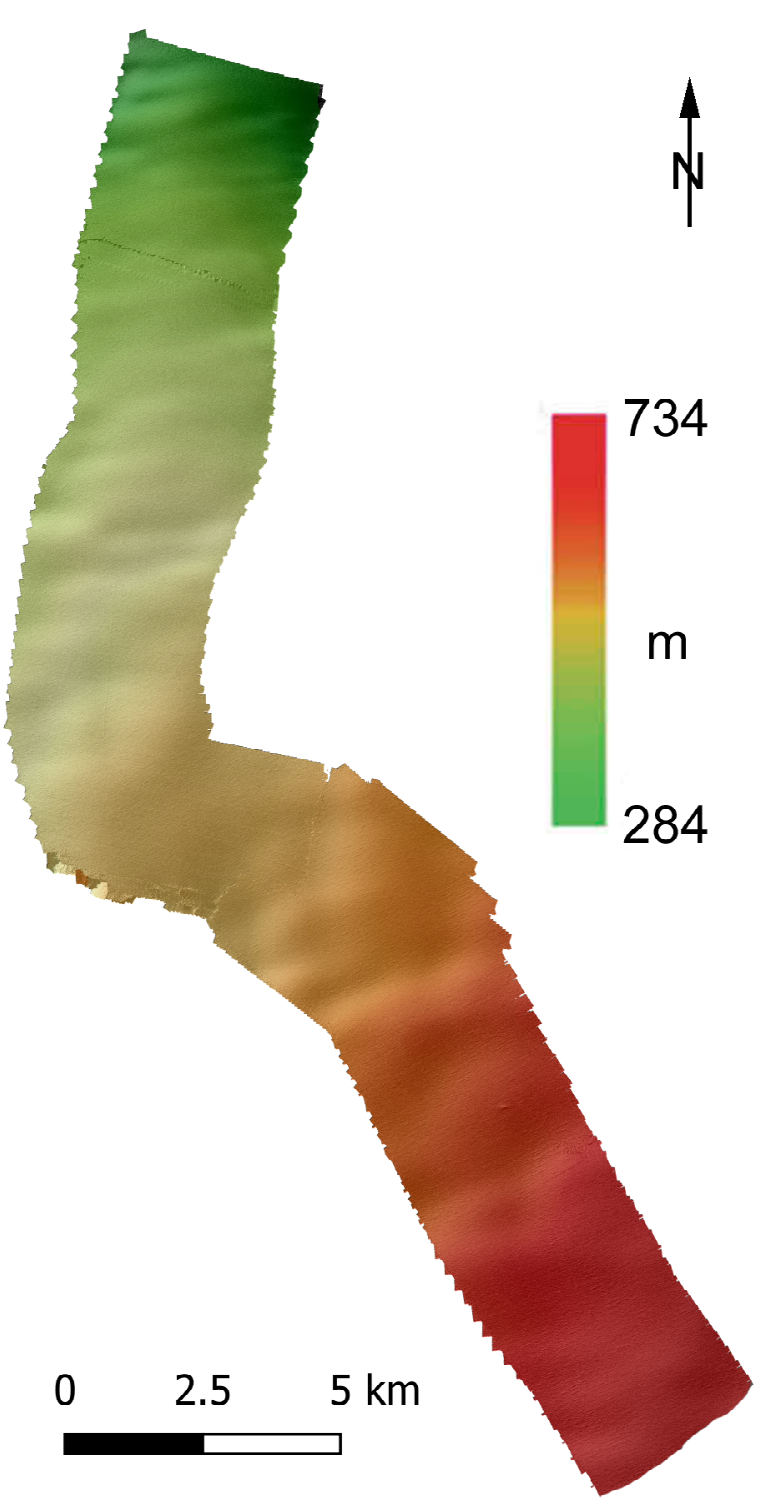

Figure 3. The area of the initial section of the sledge route from the Progress to Vostok Stations (the mid-January survey): the 1$\mathrm{m}$ gridded hill-shaded elevation model

For geomorphometric calculation, 3D modeling, and visualization, we utilize the following software: LandLord 4.0 (Florinsky, 2016), MatLab R2008b, ArcMap 10.0, ENVI Classic 2.7, QGIS 3.00, and MapInfo Pro 16.0.1.

In particular, geomorphometric treatment of the data describing the sledge route area included derivation of high-resolution hillshaded maps and construction of cross-sections (Figs. 4-8). These are used to study microtopographic snow/ice features of eolian origin, for example, elongated snow/ice patterns (which are, apparently, little sastrugi) stretching from southwest to northeast, perpendicular to the general local katabatic wind direction.

\section{CONCLUSIONS}

As a result of the ongoing project, we will develop a theory and methodology of geomorphometric modeling in the context of glaciological research in the Arctic, Antarctic, and highland regions.
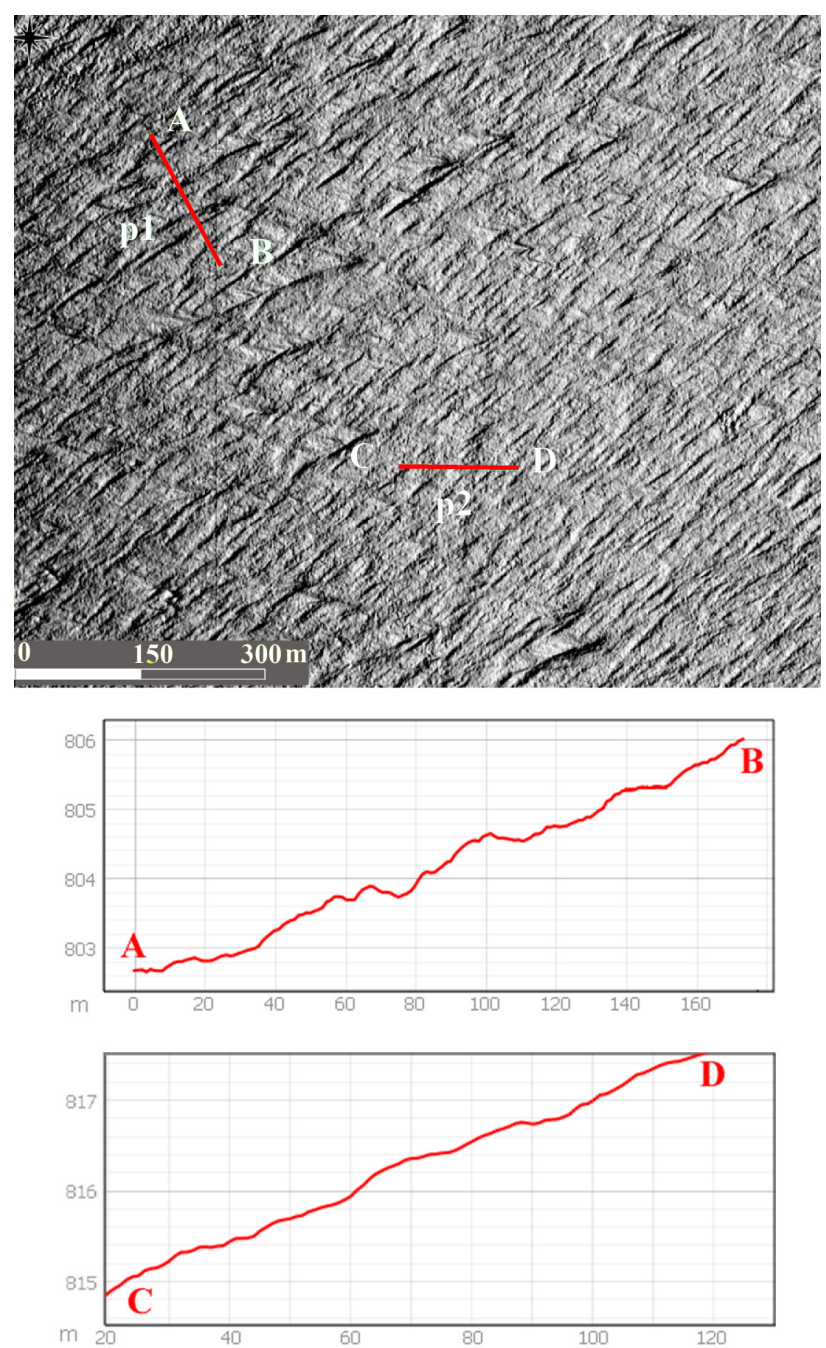

Figure 4. Microtopographic snow/ice features of eolian origin at the site 1: the 1-m gridded hill-shaded map and two crosssections $\mathrm{A}-\mathrm{B}$ and $\mathrm{C}-\mathrm{D}$. One can see snow/ice microfeatures of eolian origin. For the site location, see Fig. 1

\section{ACKNOWLEDGEMENTS}

The project is supported by the Russian Foundation for Basic Research and the National Natural Science Foundation of China, grant \# 20-51-53016.

\section{REFERENCES}

Bamber, J.L., Gomez-Dans, J.L., Griggs, J.A., 2009. A new 1 $\mathrm{km}$ digital elevation model of the Antarctic derived from combined satellite radar and laser data - Part 1: Data and methods. Cryosphere, 3(1), 101-111.

Bash, E.A., Moorman, B.J., Gunther, A., 2018. Detecting shortterm surface melt on an Arctic glacier using UAV surveys. Remote Sens., 10(10), \# 1547.

Bhambri, R., Bolch, T., 2009. Glacier mapping: A review with special reference to the Indian Himalayas. Progr. Phys. Geogr., $33(5), 672-704$ 

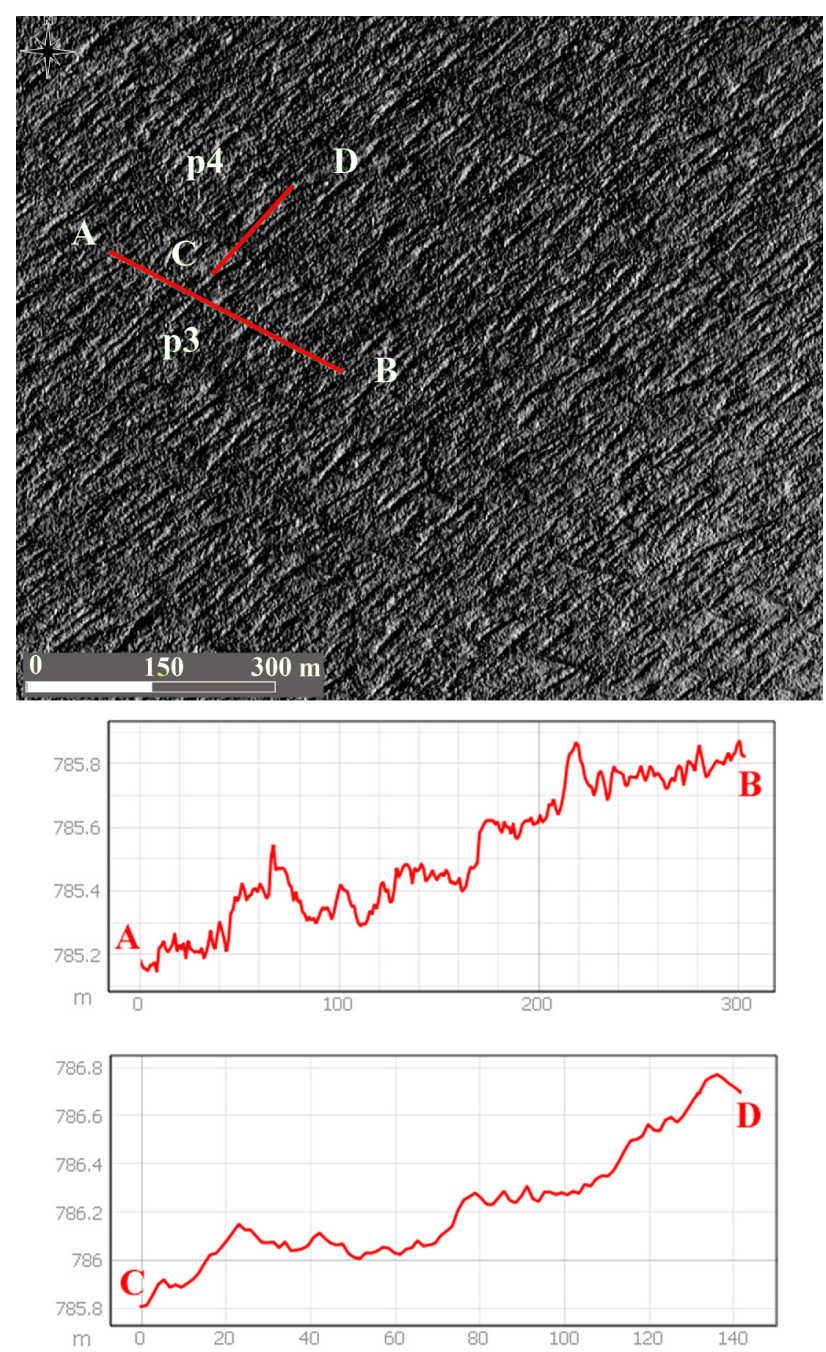

Figure 5. Microtopographic snow/ice features of eolian origin at

the site 2: the 1-m gridded hill-shaded map and two cross-

sections $\mathrm{A}-\mathrm{B}$ and $\mathrm{C}-\mathrm{D}$. One can see snow/ice microfeatures of eolian origin. For the site location, see Fig. 1

Bhardwaj, A., Sam, L., Akanksha, Martín-Torres, F.J., Kumar, R., 2016. UAVs as remote sensing platform in glaciology: Present applications and future prospects. Remote Sens. Environ., 175, 196-204.

Bliakharskii, D.P., 2019. Specifics of aerial survey of mountain and ice-sheet glaciers using unmanned aerial vehicles. Izv. Vuzov. Geod. Aerophotosurv., 63(6), 650-661 (in Russian, with English abstract).

Bliakharskii, D.P., Florinsky, I.V., Skrypitsyna, T.N., 2019a. Modelling glacier topography in Antarctica using unmanned aerial survey: Assessment of opportunities. Int. J. Remote Sens., 40(7), 2517-2541.

Bliakharskii, D.P., Volgusheva, N.E., Kazakov, E.E., 2019 b. UAS-photosurveying method for glacier monitoring during ablation season: Potanin and Alexandra glaciers, Mongolian Altai mountains. Izv. Vuzov. Geod. Aerophotosurv., 63(2), 168179 (in Russian, with English abstract).

Bliakharskii, D.P., Ishalina, O.T., Tyurin, S.V., 2020. Detection of hidden glacial crevasses using data from unmanned aerial
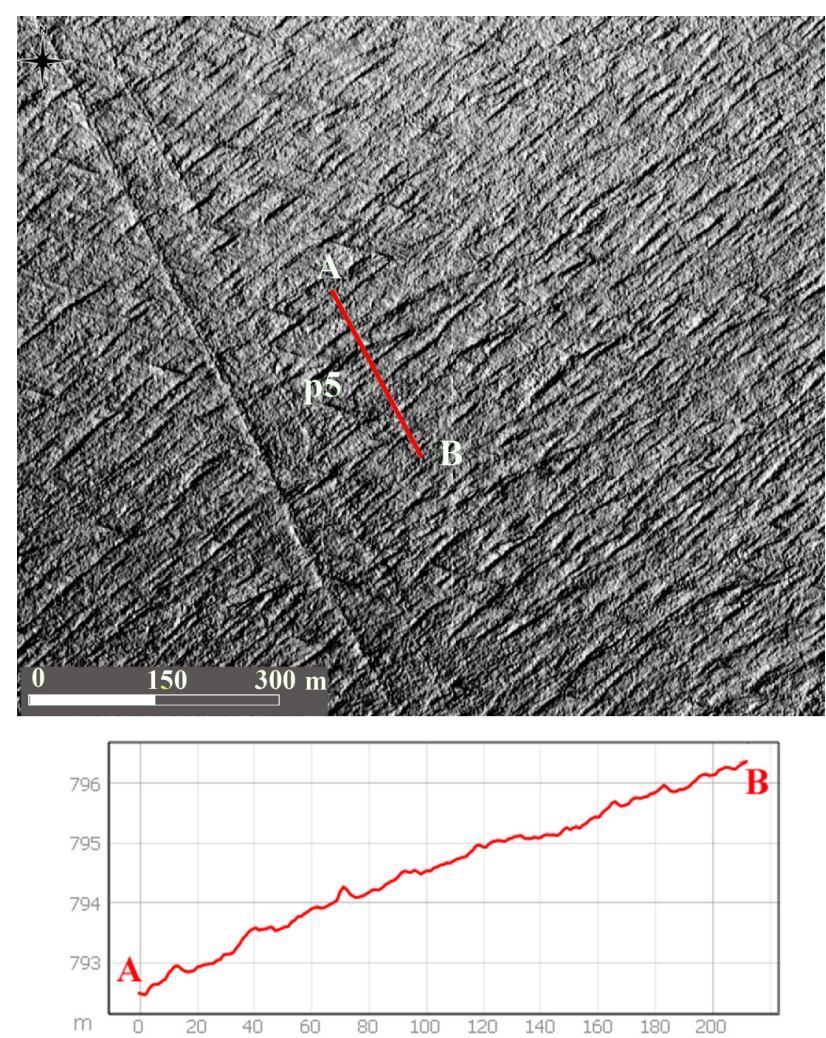

Figure 6. Microtopographic snow/ice features of eolian origin at the site 3: the 1-m gridded hill-shaded map and a cross-section A-B. One can see snow/ice microfeatures of eolian origin, as well as the sledge route crossing the site. For the site location, see Fig. 1

survey in the area of the Progress Station (East Antarctica). Izv. Vuzov. Geod. Aerophotosurv., 64(1), 45-53 (in Russian, with English abstract).

Boyko, E.S., 2010. Microtopography as a Factor of Snow Formation in the Mountains Using Airborne Laser Scanned Data. Summary of Ph.D. Thesis. Kuban State University, Krasnodar (in Russian).

Chiang, K.-W., Tsai, M.-L., Chu, C.-H., 2012. The development of an UAV borne direct georeferenced photogrammetric platform for ground control point free applications. Sensors, 12(7), 9161-9180.

DiMarzio, J.P., Brenner, A.C., Fricker, H.A., Schutz, B.E., Shuman, C.A., Zwally, H.J., 2005. Digital elevation models of the Antarctic and Greenland ice sheets from ICESat. In American Geophysical Union, Fall Meeting 2005, abstract \# C51B-0276.

Etzelmüller, B., 2000. On the quantification of surface changes using grid-based digital elevation models (DEMs). Trans. GIS, 4(2), 129-143.

Etzelmüller, B., Sollid, J.L., 1997. Glacier geomorphometry An approach for analysing long-term glacier surface changes using grid-based digital elevation models. Ann. Glaciol., 24, 135-141. 

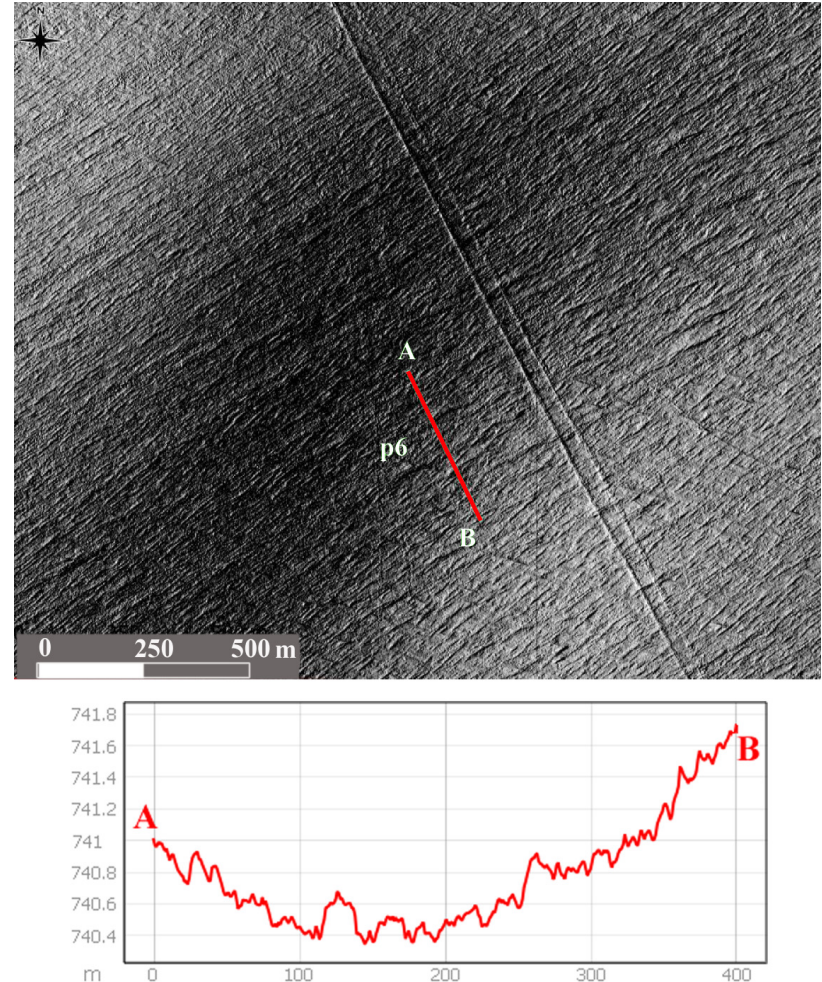

Figure 7. Microtopographic snow/ice features of eolian origin at the site 4: the 1-m gridded hill-shaded map and a cross-section A-B. One can see snow/ice microfeatures of eolian origin, as well as the sledge route crossing the site. For the site location, see Fig. 1

Florinsky, I.V., 2016. Digital Terrain Analysis in Soil Science and Geology. 2nd ed. Academic Press, Amsterdam.

Florinsky, I.V., 2017. An illustrated introduction to general geomorphometry. Progr. Phys. Geogr., 41(6), 723-752.

Florinsky, I.V., Bliakharskii, D.P., 2019a. Detection of crevasses by geomorphometric treatment of data from unmanned aerial surveys. Remote Sens. Lett., 10(4), 323-332.

Florinsky, I.V., Bliakharskii, D.P., 2019b. The 2017 catastrophic subsidence in the Dålk Glacier, East Antarctica: Unmanned aerial survey and terrain modelling. Remote Sens. Lett., 10(4), 333-342.

Florinsky, I.V., Kurkov, V.M., Bliakharskii, D.P., 2018. Geomorphometry from unmanned aerial surveys. Trans. GIS, 22(1), 58-81.

Fox, A.J., Cziferszky, A., 2008. Unlocking the time-capsule of historic aerial photography to measure changes in Antarctic Peninsula glaciers. Photogramm. Rec., 23(121), 51-68.

Fretwell, P., Pritchard, H.D., Vaughan, D.G., Bamber, J.L., Barrand, N.E., Bell, R., Bianchi, C., et al., 2013. Bedmap2: Improved ice bed, surface and thickness datasets for Antarctica. Cryosphere, 7(1), 375-393.

Geoscan, 2016. Geoscan 201 Geodesy. Saint-Petersburg, Russia: Geoscan Ltd, https://www.geoscan.aero/en/products/ geoscan201/geo/ (28 April 2020).
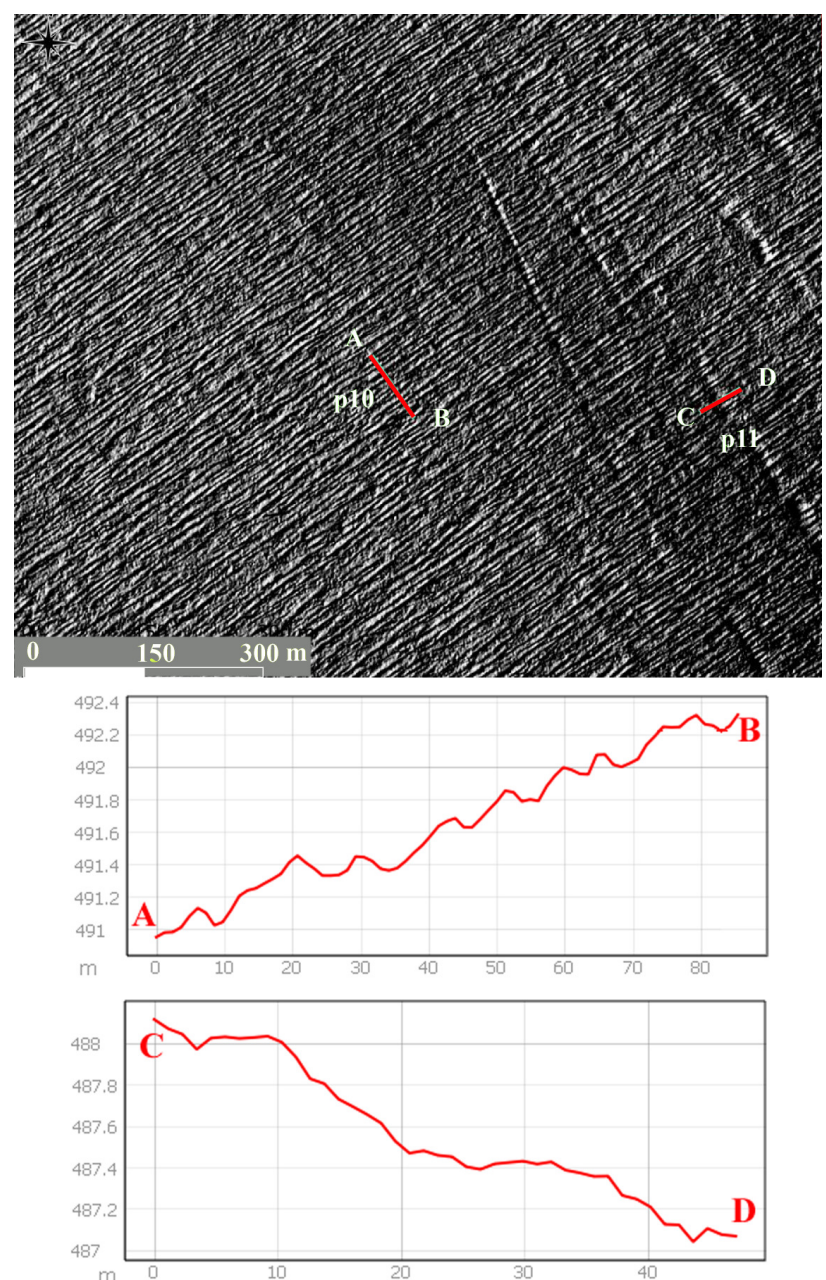

Figure 8. Microtopographic snow/ice features of eolian origin at the site 7: the 1-m gridded hill-shaded map and two crosssections $\mathrm{A}-\mathrm{B}$ and $\mathrm{C}-\mathrm{D}$. One can see snow/ice microfeatures of eolian origin, as well as several crevasses. For the site location, see Fig. 1

Helm, V., Humbert, A., Miller, H., 2014. Elevation and elevation change of Greenland and Antarctica derived from CryoSat-2. Cryosphere, 8(4), 1539-1559.

Hengl, T., Reuter, H.I. (Eds.), 2009. Geomorphometry: Concepts, Software, Applications. Elsevier, Amsterdam.

Hodson, A., Anesio, A.M., Ng, F., Watson, R., Quirk, J., IrvineFynn, T., Sattler, B., 2007. A glacier respires: Quantifying the distribution and respiration $\mathrm{CO}_{2}$ flux of cryoconite across an entire Arctic supraglacial ecosystem. J. Geophys. Res., 112, \# G04S36.

Immerzeel, W.W., Kraaijenbrink, P.D.A., Shea, J.M., Shrestha, A.B., Pellicciotti, F., Bierkens, M.F.P., de Jong, S.M., 2014. High-resolution monitoring of Himalayan glacier dynamics using unmanned aerial vehicles. Remote Sens. Environ., 150, 93-103.

Jouvet, G., Weidmann, Y., Seguinot, J., Funk, M., Abe, T., Sakakibara, D., Seddik, H., Sugiyama, S., 2017. Initiation of a major calving event on the Bowdoin Glacier captured by UAV photogrammetry. Cryosphere, 11, 911-921. 
Kääb, A., 2008. Glacier volume changes using ASTER satellite stereo and ICESat GLAS laser altimetry. A test study on Edgeøya, Eastern Svalbard. IEEE Trans. Geosci. Remote Sens., 46(10), 2823-2830.

Knizhnikov, Y.F., Zolotarev, E.A., Kravtsova, V.I., and Kharkovets, E.G., 2000. Remote sensing monitoring of mountain glaciers: Technology changes in the last 50 years (exemplified by Mount Elbrus). Data Glaciol. Stud., 89, 58-64 (in Russian, with English abstract).

Knizhnikov, Y.F., Gelman, R.N., Popovnin, V.V., and Zhukov, A.V., 2002. Field studies of mountain glaciers: Metric feasibility of stereo photographs obtained by digital cameras. Data Glaciol. Stud., 92, 216-222 (in Russian, with English abstract).

Kraaijenbrink, P.D.A., Shea, J.M., Pellicciotti, F., de Jong, S.M., Immerzeel, W.W., 2016. Object-based analysis of unmanned aerial vehicle imagery to map and characterise surface features on a debris-covered glacier. Remote Sens. Environ., 186, 581-595.

Petrakov, D.A., Aristov, K.A., Aleynikov, A.A., Boyko, E.S., Drobyshev, V.N., Kovalenko, N.V., Tutubalina, O.V., Chernomorets, S.S., 2018. Rapid regeneration of the Kolka Glacier (Caucasus) after the 2002 glacial disaster. Earth Cryosphere, 22(1), 58-71 (in Russian, with English abstract).

Pogorelov, A.V., 1999. Study of the structure of snow reserves in the mountain basin and their evaluation using digital elevation models. Data Glaciol. Stud., 86, 160-164 (in Russian).

Pogorelov, A.V., Boyko, E.S., Petrakov, D.A., and Kiselev, E.N., 2017. Fluctuations of the Fisht Glacier (West Caucasus) over 1909-2015. Ice Snow, 57(4), 498-506 (in Russian, with English abstract)

Racoviteanu, A.E., Manley, W.F., Arnaud, Y., Williams, M.W., 2007. Evaluating digital elevation models for glaciologic applications: An example from Nevado Coropuna, Peruvian Andes. Global Planet. Change, 59(1-4), 110-125.

Rippin, D., Willis, I., Arnold, N., Hodson, A., Moore, J., Kohler, J., BjöRnsson, H., 2003. Changes in geometry and subglacial drainage of Midre Lovénbreen, Svalbard, determined from digital elevation models. Earth Surface Process. Landforms, 28(3), 273-298.

Rippin, D.M., Pomfret, A., King, N., 2015. High resolution mapping of supra-glacial drainage pathways reveals link between micro-channel drainage density, surface roughness and surface reflectance. Earth Surface Process. Landforms, 40(10), 1279-1290.

Ryan, J.C., Hubbard, A.L., Box, J.E., Todd, J., Christoffersen, P., Carr, J.R., Holt, T.O., Snooke, N., 2015. UAV photogrammetry and structure from motion to assess calving dynamics at Store Glacier, a large outlet draining the Greenland ice sheet. Cryosphere, 9(1), 1-11.

Shary, P.A., Sharaya, L.S., Mitusov, A.V., 2002. Fundamental quantitative methods of land surface analysis. Geoderma, 107(1-2), 1-32.
Semakova, E.R., and Semakov, D.G., 2017. On a possibility to use the remote sensing techniques for glaciological analysis in mountain regions of Uzbekistan. Ice Snow, 57(2), 185-199 (in Russian, with English abstract).

Stüwe, K., Braun, H.-M., Peer, H., 1989. Geology and structure of the Larsemann Hills area, Prydz Bay, East Antarctica. Austral. J. Earth Sci., 36(2), 219-241.

Suetova, I.A., and Chistov, S.V., 1993. Study of ice dynamics in the Antarctic by computer modelling. Geod. Cartogr., 3, 4550 (in Russian).

Turner, D., Lucieer, A., Wallace, L., 2014. Direct georeferencing of ultrahigh-resolution UAV imagery. IEEE Trans. Geosci. Remote Sens., 52(5), 2738-2745.

Whitehead, K., Moorman, B.J., Hugenholtz, C.H., 2013. Lowcost, on-demand aerial photogrammetry for glaciological measurement. Cryosphere, 7(6), 1879-1884.

Wigmore, O., Mark, B., 2017. Monitoring tropical debriscovered glacier dynamics from high-resolution unmanned aerial vehicle photogrammetry, Cordillera Blanca, Peru. Cryosphere, $11,2463-2480$.

Wilson, J.P., 2018. Environmental Applications of Digital Terrain Modeling. Wiley-Blackwell, Chichester.

Wilson, J.P., Gallant, J.C. (Eds.), 2000. Terrain Analysis: Principles and Applications. Wiley, New York.

Zolotarev, E.A., 2009. Evolution of the Elbrus Glaciation. Cartographic-Aerospace Technologies for Glaciological Monitoring. Nauchny Mir, Moscow (in Russian, with English abstract). 